\title{
RANCANG BANGUN WEBSITE \\ PADA PT. BPR SYARIAH \\ GEBU PRIMA
}

\author{
Windra Pratama, Dedi Wahyudi, Wahyu Sri haryani \\ Alumni Sekolah Tinggi Ilmu Manajemen Sukma \\ Program studi Manajemen, Sekolah Tinggi Ilmu Manajemen \\ dediw7084@gmail.com, wahyusriharyani@gmail.com
}

\begin{abstract}
The purpose of this study was conducted because at PT. Sharia Rural Bank Gebu Prima still has no official website to be seen by the general public so that the public has not much to know about the company profile. Design This website is one of the sites that can meet the needs and improve services at PT. Bank Perkreditan Rakyat Syariah Gebu Prima. The application will be built using Adobe Dreamweaver CS3 software type. Adobe Dreamweaver is an application that serves to edit website pages. The research has been successfully implemented so that the future can improve service and can be accessed more widely by the general public who want to know the profile at PT. Bank Perkreditan Rakyat Syariah Gebu Prima.
\end{abstract}

Keywords: Design Build, Company Website

\section{PENDAHULUAN}

Perkembangan internet dan network yang semakin maju dan luas membuat beberapa perusahaan membutuhkan sebuah situs web untuk mempermudah mempromosikan, memperkenalkan dan memberikan informasi kepada masyarakat tentang profil perusahaannya dan untuk memberikan informasi kepada kantor - kantor cabang tentang berbagai promo. Jika melalui media cetak atau media lainnya sangat terbatas sehingga informasi yang diperoleh kurang update dan biaya yang dikeluarkan lebih mahal dibanding kan melalui website.

Penelitian yang dilakukan oleh Kurniawan (2013) dengan judul Perancangan website profil bisnis pada pabrik gula PT. Gondang Baru Klaten, dari hasil penelitian menunjukkan bahwa Website PT. Gondang Baru sebagai media promosi yang dapat meningkatkan kualitas penyampaian dan penyebaran informasi yang lebih luas, Selain sebagai media promosi, sistem website PT Gondang Baru dilengkapi dengan fitur Online Booking untuk pemesanan gedung maupun homestay bagi member yang telah registrasi. Administrator diberi fasilitas guna mengatur Online Booking. Berdasarkan hasil analisis kebutuhan diketahui bahwa fitur pendukung sebagai media promosi yaitu Online Booking bagi member yang telah registrasi dan Blog. Penelitian yang dilakukan Sudarsono (2012) menyatakan bahwa Lembaga keuangan yang usaha pokoknya memberikan kredit atau pembiayaan dan jasa-jasa lainnya dalam lalu lintas pembayaran serta peredaran uang yang pengoperasiannya, disesuaikan dengan prinsip - prinsip syariah.

\section{Perumusan Masalah}

Perumusan masalah penelitian ini yaitu Bagaimana merancang dan membangun Website Pada PT. Bank Perkreditan Rakyat Syariah Gebu Prima. 


\section{Batasan Masalah}

Penelitian ini dibatasi pada merancang dan bangun Website PT. Bank Perkreditan Rakyat Syariah Gebu Prima menggunakan bahasa program Adobe Dreamweaver, dan garis besar website tersebut adalah sejarah, profil perusahaan serta produk - produk yang ada pada PT. Bank Perkreditan Rakyat Syariah Gebu Prima, dalam website ini pengguna (user) hanya dapat melihat postingan Admin dan tidak ada proses input.

\section{Tujuan Penelitian}

Adapun tujuan penelitian ini adalah untuk merancang dan membangun sebuah Website Pada PT. Bank Perkreditan Rakyat Syariah Gebu Prima untuk meningkatkan pelayanan.

\section{METODE PENELITIAN}

\section{Metode Analisis Data}

Adapun metode analisis data yang digunakan dalam merancang dan membangun Website pada PT BPR Syariah Gebu Prima adalah sebagai berikut:

1. Perangkat Keras (Hardware)

Perangkat keras yang digunakan dalam merancang bangun dan memproses penelitian ini menggunakan processor Core i3 memori 500GB dan RAM 2 GB.

2. Perangkat Lunak (Software)

Perangkat lunak yang digunakan dalam penelitian ini menggunakan sistem operasi Microsoft Windows 7 dengan aplikasi pemograman yaitu Adobe Dreamweaver CS3, Photosop.

\section{Perancangan (Web Design)}

Istilah Umum Design web yang digunakan untuk mencakup bagaimana isi web yang ditampilkan. Tipe Web Design ada 3 model yaitu Design Fixed, Design Fluid, dan Design Elastic. Website ini menggunakan tipe web jenis Design Elastic karna tampilan ukuran font dapat menyesuaikan diri setiap kali terjadi perubahan resolusi layar. Jika designer web menggunakan tipe ini, layout akan sesuai dengan berbagai ukuran dan resolusi layar yang berbeda sehingga dapat menyediakan visibilitas pengguna web yang menyenangkan. Jenis huruf yang digunakan pada web ini adalah Times New Roman. Contoh rancangan web design sebagai berikut :

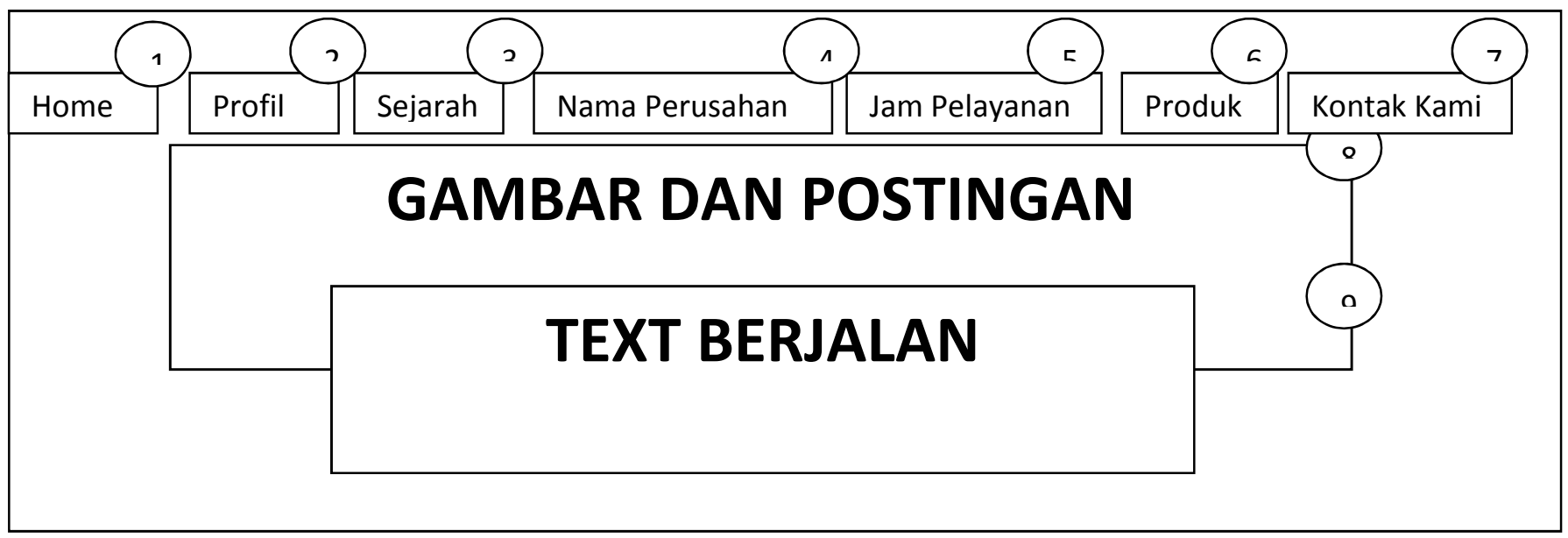

Gambar 1. Perancangan ( Web Design ) 
Keterangan :

1. Home - Halaman Home ( menu utama ) menampilkan gambar Komisaris, Dewan Komisaris dan Perusahaan.

2. Profil - Halaman Profil menampilkan gambar kegiatan dan aktifitas perusahaan.

3. Sejarah - Halaman Sejarah menampilkan latar belakang Berdirinya perusahaan.

4. Nama Perusahaan - Nama Website perusahaan

5. Jam Pelayanan - Halaman Jam Pelayanan menampilkan waktu operasional perusahaan.

6. Produk - Halaman ini menampilkan Produk yang ada pada perusahaan.

7. Kontak kami - Halaman ini menampilkan social media dan lokasi perusahaan.

8. Gambar dan Postingan - Halaman ini menampilkan Gambar tentang perusahaan atau postingan produk perusahaan.

Iklan Berjalan - Halaman ini menampilkan Visi perusahaan secara slide

\section{HASIL DAN PEMBAHASAN}

\section{Perancangan Data flow Diagram}

Perancangan yang digunakan dalam penelitian ini menggunakan rancangan data flow diagram, sebagai berikut :

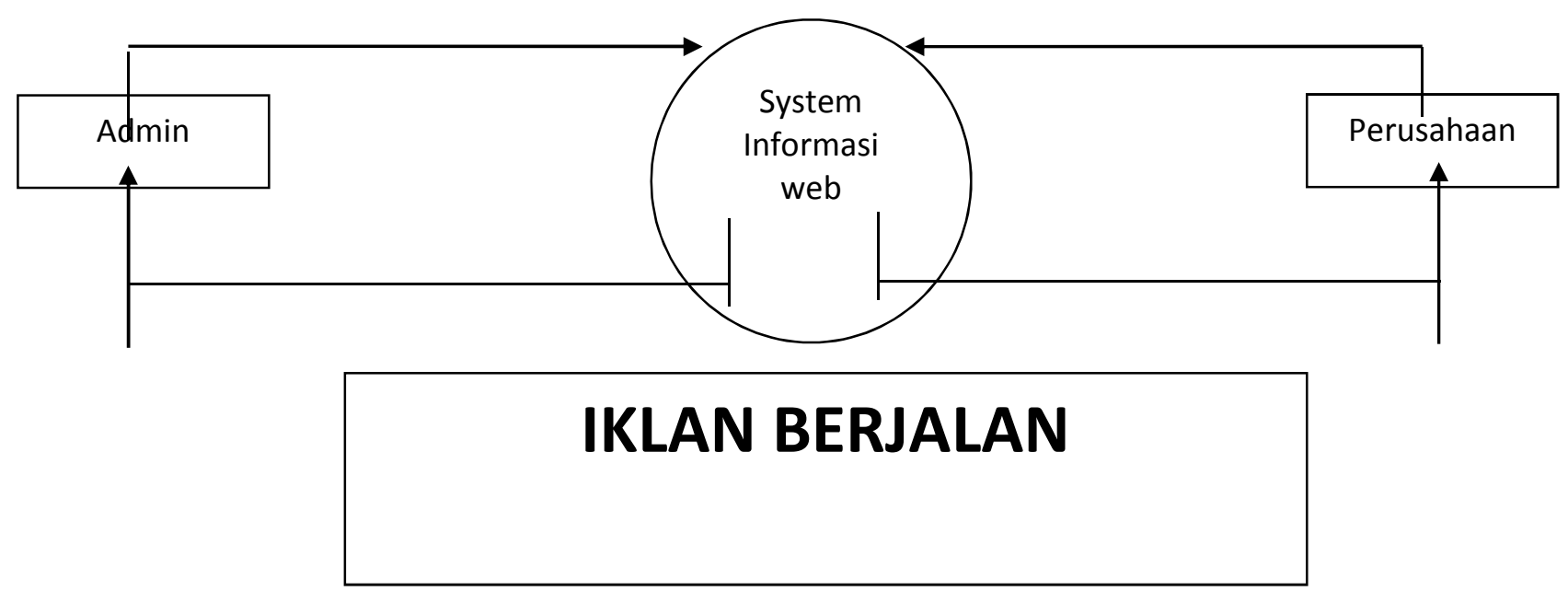

Gambar 2. Rancangan Data Diagram

Rancangan data diagram ini menunjukan bahwa ada dua entitas yang terlihat yaitu, admin dan perusahanan. Diagram tersebut menunjukan admin dapat mengakses system informasi website dan perusahaan dapat mengakses system informasi melalui admin sesuai dengan ketentuan yang ada dalam perusahaan

\section{Tampilan Awal Halaman Aplikasi}

Pada sub bab ini akan dibahas mengenai aplikasi web yang telah dibuat. Sesuai dengan identifikasi masalah yaitu bagaimana membuat website pada PT. BPR Syariah Gebu Prima, berikut uraian pembahasan setelah penulis melakukan perancangan sistem, maka hasil penelitian yang telah diselesaikan adalah sebagai berikut :

1. Halaman awal website (HOME)

Halaman ini menampilkan halaman utama Website PT. Bank Perkreditan Rakyat Syariah Gebu Prima. 


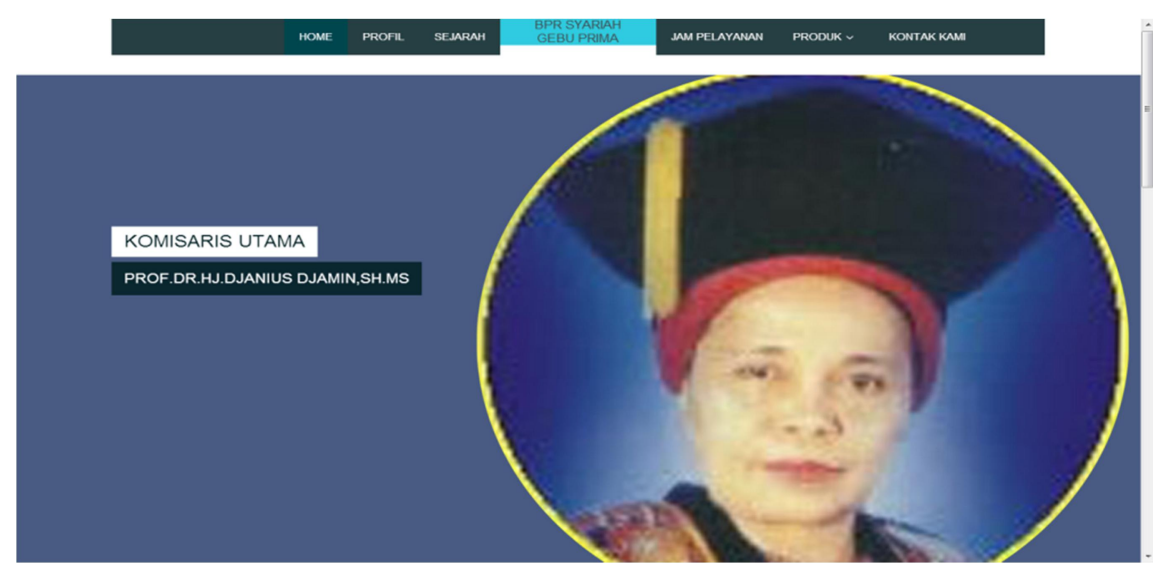

Gambar 3. Tampilan Halaman Home

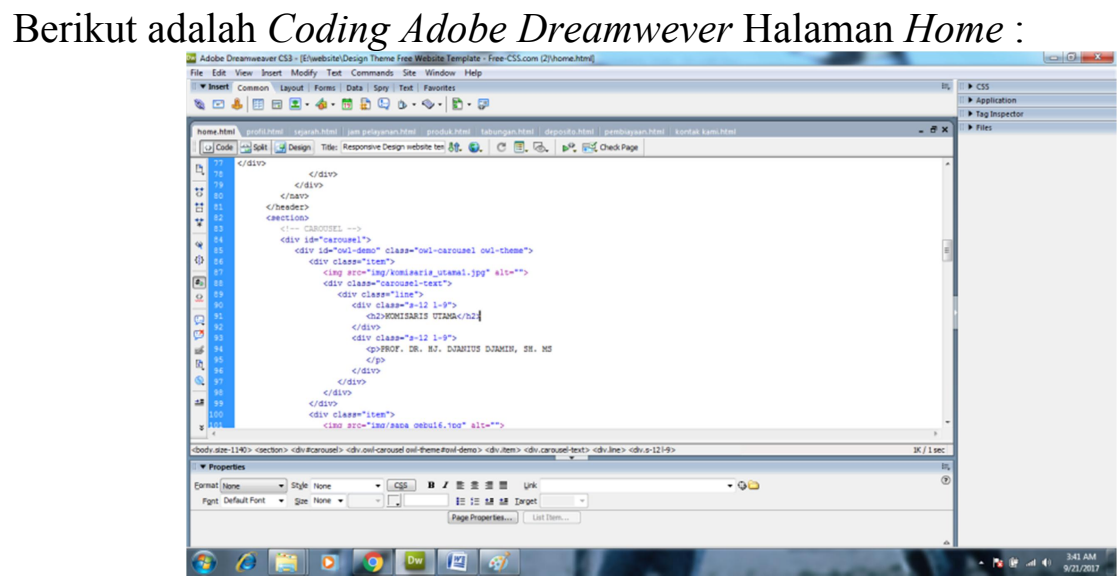

Gambar 4. Coding Halaman Home.

Pada coding ini terdapat tampilan halaman Home yang menampilkan Link Home, Profil, sejarah, jam pelayanan, produk dan kontak kami dan masing - masing bisa di edit pada Adobe Dreamwever. Inti dari halaman ini menampilkan gambar Komisaris utama.

Contoh Coding :

$<$ div id="carousel" $>$

$<$ div id="owl-demo" class="owl-carousel owl-theme" $>$

$<$ div class="item" $>$

$<$ img src="img/komisaris utama1.jpg" alt="">

$<$ div class $=$ "carousel-text" $><$ div class $="$ line" $>$

$<$ div class="s-12 1-9"> $<$ h2 $>$ KOMISARIS UTAMA $</ \mathrm{h} 2>$

$</$ div $>$

2. Tampilan Halaman PROFIL

Pada halaman ini akan ditampilkan kegiatan yang telah dilakukan PT. Bank Perkreditan Rakyat Syariah Gebu Prima, sehingga user dapat mengetahui apa saja kegiatan pada PT. Bank Perkreditan Rakyat Syariah Gebu Prima.
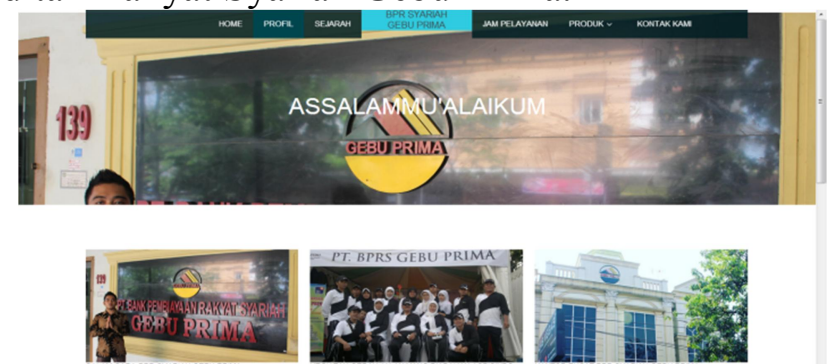

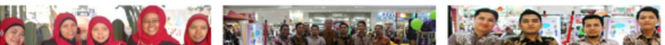

Gambar 5. Tampilan Halaman Profil. 


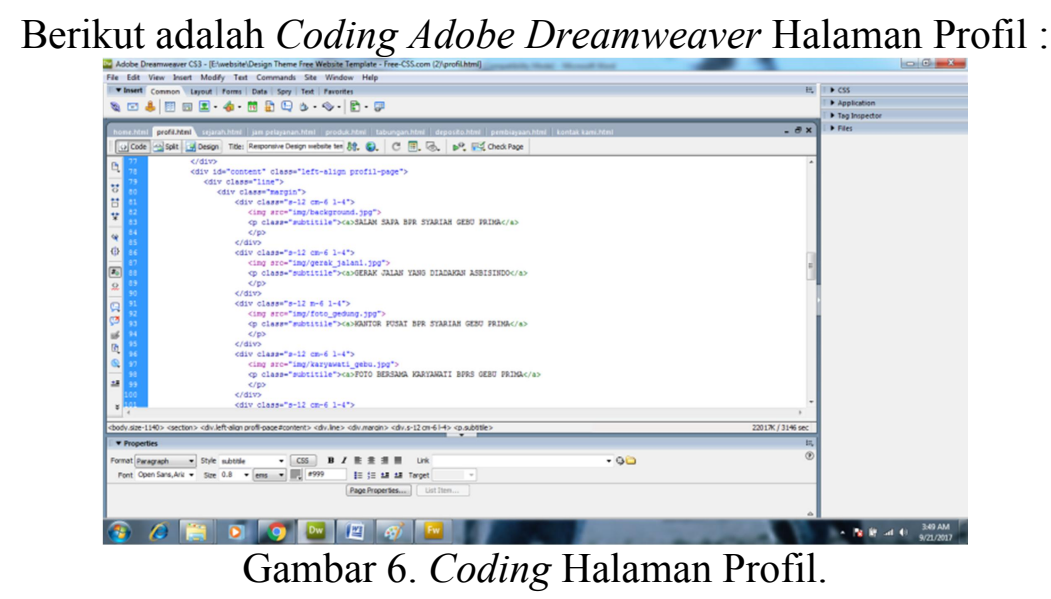

Pada coding ini terdapat tampilan halaman Profil yang menampilkan Link Home, Profil, sejarah, jam pelayanan, produk dan kontak kami dan masing - masing bisa di edit pada Adobe Dreamwever. Inti dari halaman ini menampilkan gambar kegiatan yang ada pada PT. Bank Perkreditan Rakyat Syariah Gebu Prima.

Contoh Coding :

$$
\begin{aligned}
& <\text { div class="margin" }> \\
& <\text { div class="s-12 cm-6 1-4" }> \\
& <\text { a href="img/background.JPG" }><\text { img src="img/background.jpg" }></ \text { a }> \\
& <\text { p class }=\text { "subtitile" }><\text { a }>\text { SALAM SAPA BPR SYARIAH GEBU PRIMA }</ \text { a }> \\
& </ \text { p }>
\end{aligned}
$$

\section{Tampilan Halaman SEJARAH}

Halaman ini akan menampilkan sejarah singkat perusahaan, tahun berdiri serta perkembangan PT. Bank Perkreditan Rakyat Syariah Gebu Prima hingga sekarang, sehingga user dapat mengetahui informasi tentang sejarah PT. Bank Perkreditan Rakyat Syariah Gebu Prima.

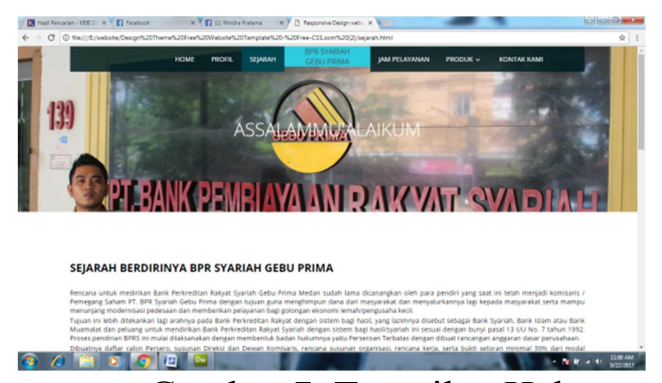

Gambar 7. Tampilan Halaman Sejarah

Berikut adalah Coding Adobe Dreamweaver Halaman Sejarah :

Gambar 4.8. Tampilan Halaman Sejarah.

Pada coding ini terdapat tampilan halaman Sejarah yang menampilkan Link Home, Profil, sejarah, jam pelayanan, produk dan kontak kami dan masing - masing bisa di edit pada Adobe Dreamwever. Inti dari halaman ini menampilkan sejarah singkat perusahaan, tahun berdiri serta perkembangan PT. Bank Perkreditan Rakyat Syariah Gebu Prima hingga sekarang, sehingga user dapat mengetahui informasi tentang sejarah PT. Bank Perkreditan Rakyat Syariah Gebu Prima.

Contoh Coding $:<\mathrm{h} 6$ class="style7" $>$ \&nbsp; $\quad</ \mathrm{h} 6>$

$<$ h6 align="justify" class="style9" $>$ Rencana untuk medirikan Bank Perkreditan Rakyat Syariah Gebu Prima Medan sudah lama dicanangkan oleh para pendiri yang saat ini 
telah menjadi komisaris / Pemegang Saham PT. BPR Syariah $\quad</$ h6 $>$

$<$ /blockquote $>\quad<$ /blockquote $>\quad<$ /blockquote $>$

4. Tampilan Halaman JAM PELAYANAN

Halaman ini akan menampilkan hari dan waktu kerja PT. Bank Perkreditan Rakyat Syariah Gebu Prima sehingga nasabah mengetahui waktu operasional PT. Bank Perkreditan Rakyat Syariah Gebu Prima.

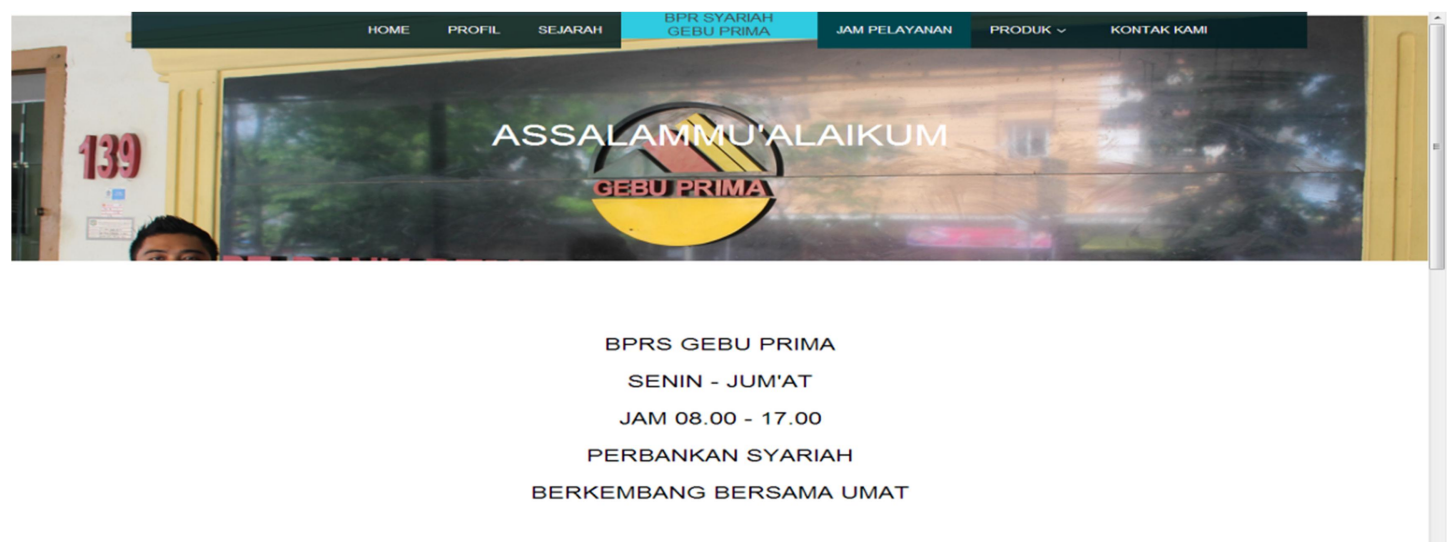

Gambar 9. Tampilan Halaman Jam Pelayanan

Berikut adalah Coding Adobe Dreamwever Halaman Jam Pelayanan :
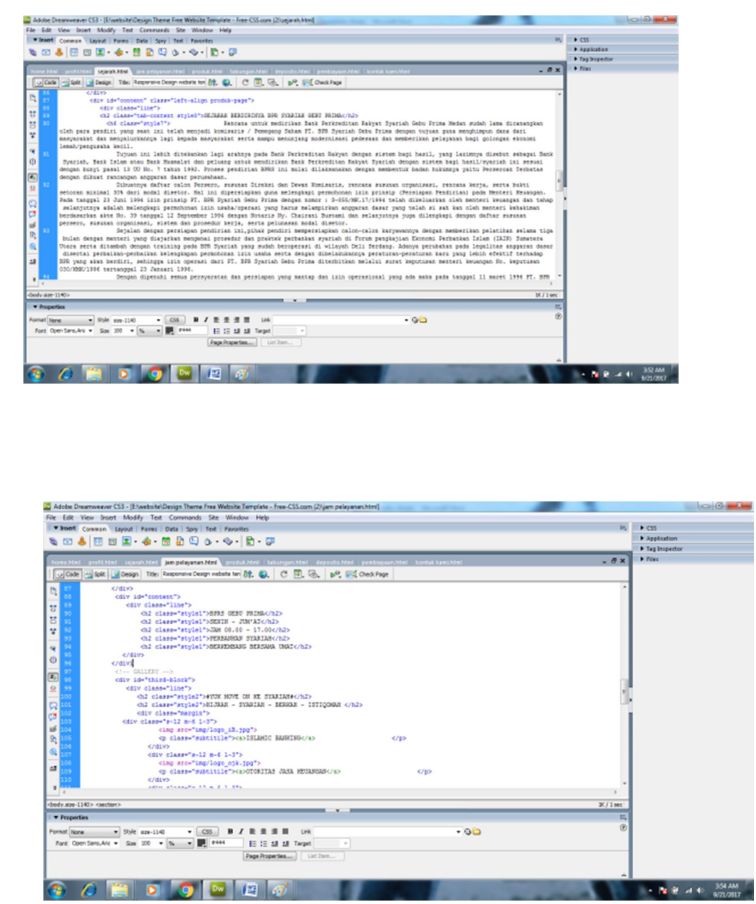

Gambar 10. Gambar Coding Halaman Jam Pelayanan.

Pada coding ini terdapat tampilan halaman Jam Pelayanan yang menampilkan Link Home, Profil, sejarah, jam pelayanan, produk dan kontak kami dan masing - masing bisa di edit pada Adobe Dreamwever. Inti dari halaman ini menampilkan hari dan waktu kerja, sehingga nasabah mengetahui waktu operasional PT. Bank Perkreditan Rakyat Syariah Gebu Prima.

Contoh Coding :

$<$ div class $="$ line" $><$ h2 class $=$ "style1" $>$ BPRS GEBU PRIMA $</ \mathrm{h} 2>$

$<\mathrm{h} 2$ class $=$ "style 1 " $>$ SENIN - JUM'AT $</ \mathrm{h} 2>$

$<$ h2 class $=$ "style 1 " $>$ JAM $08.00-17.00</ \mathrm{h} 2>$

$<$ h2 class $=$ "style1" $>$ PERBANKAN SYARIAH $</$ h2 $>$ 
5. Tampilan Halaman Produk

Halaman ini akan menampilkan apa saja produk terkini yang sedang berlangsung baik tabungan, deposito sampai pembiayaan sehingga nasabah dan calon nasabah lebih mudah untuk mendapatkan informasi pada PT. Bank Perkreditan Rakyat Syariah Gebu Prima.

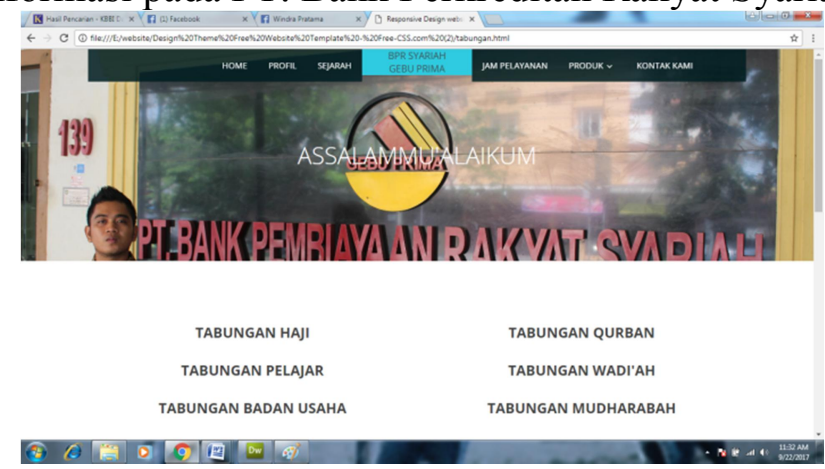

Gambar 11. Tampilan Halaman Produk

Berikut adalah Coding Adobe Dreamwever Halaman Produk :

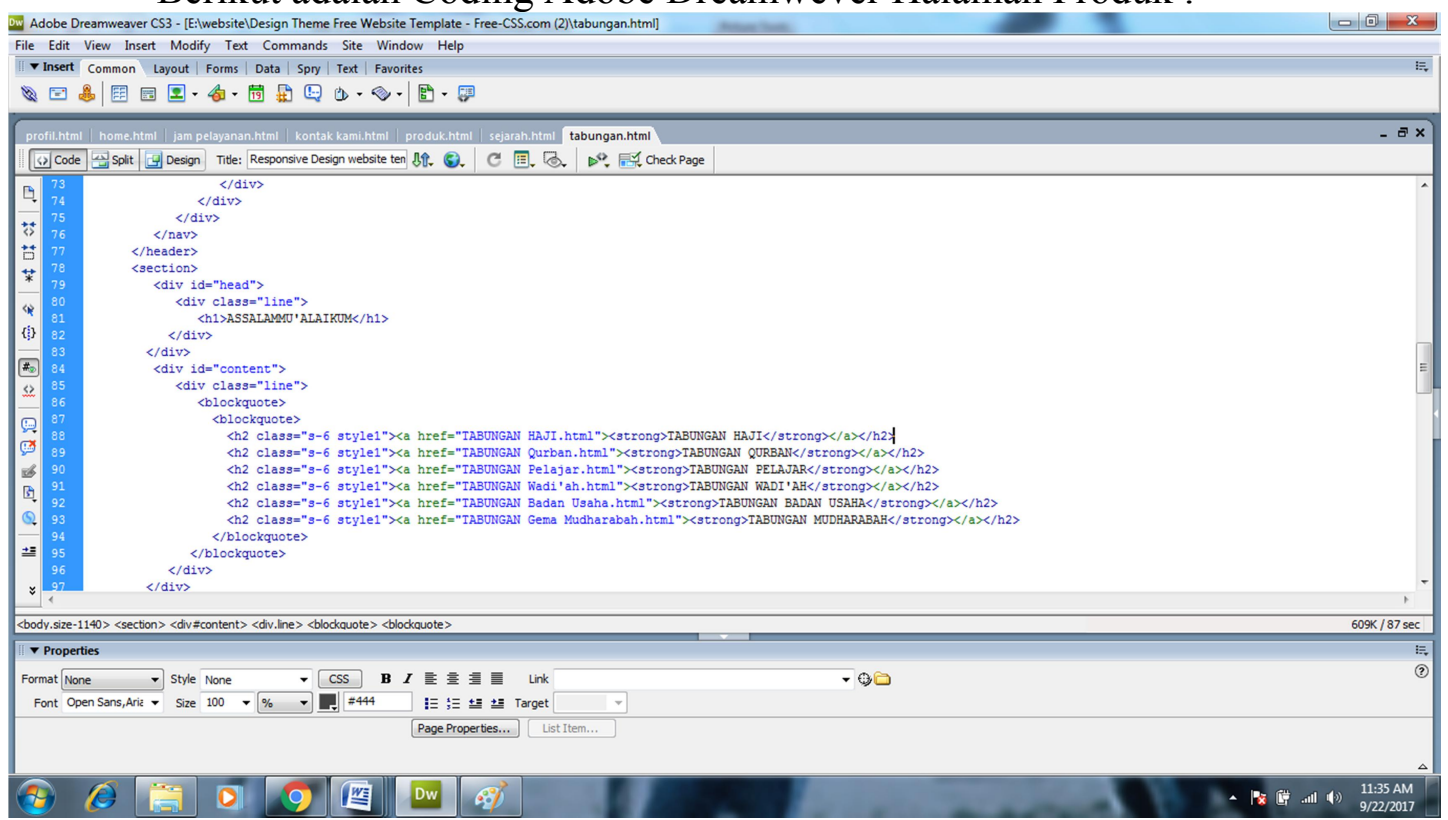

Gambar 12. Gambar Coding Halaman Produk.

Pada coding ini terdapat tampilan halaman Produk yang menampilkan Link Home, Profil, sejarah, jam pelayanan, produk dan kontak kami dan masing - masing bisa di edit pada Adobe Dreamwever. Inti dari halaman ini menampilkan apa saja produk terkini yang sedang berlangsung baik tabungan, deposito sampai pembiayaan sehingga nasabah dan calon nasabah lebih mudah untuk mendapatkan informasi pada PT. Bank Perkreditan Rakyat Syariah Gebu Prima.

Contoh Coding : $\quad<$ blockquote $>\quad<$ h2class="s-6style1" $>$

$<$ ahref="TABUNGANHAJI.html" $><$ strong $>$ TABUNGANHAJI $</$ strong $></$ a $></$ h2 $>$

$<$ h2class="s-6 style1" $><$ a href="TABUNGAN Qurban.html" $><$ strong $>$ TABUNGAN QURBAN $</$ strong $></$ a $></$ h $2>$

$<$ h2 class $=$ "s- 6 style $1 "><$ a href $=$ "TABUNGAN $<$ /blockquote $>$

\section{Tampilan Halaman Kontak Kami}

Halaman ini akan menampilkan alamat, media social serta peta lokasi PT. Bank Perkreditan Rakyat Syariah Gebu Prima. 


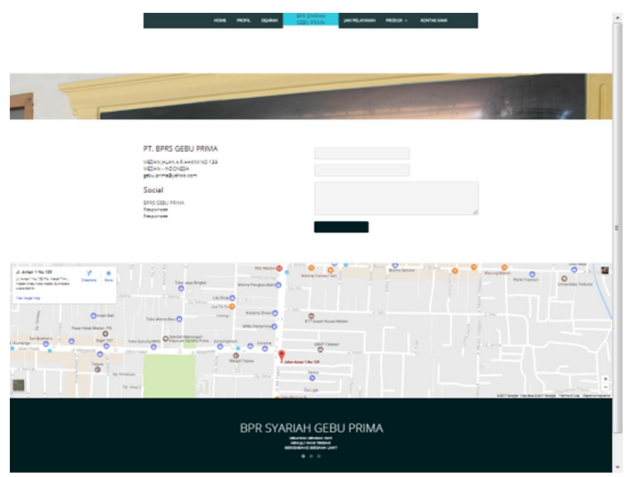

Gambar 13. Tampilan Halaman Kotak Kami

Berikut adalah Coding Adobe Dreamwever Halaman Kontak Kami :

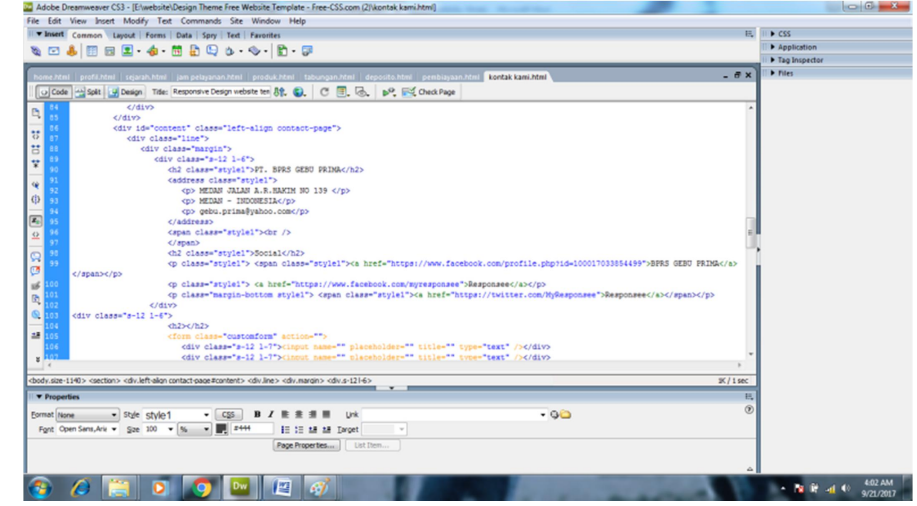

Gambar 14. Coding Halaman Kontak Kami.

Pada coding ini terdapat tampilan halaman Kontak Kami yang menampilkan Link Home, Profil, sejarah, jam pelayanan, produk dan kontak kami dan masing - masing bisa di edit pada Adobe Dreamwever. Inti dari halaman ini menampilkan alamat, media social serta peta lokasi PT. Bank Perkreditan Rakyat Syariah Gebu Prima.

Contoh Coding :

$<$ h2 class $=$ "style1" $>$ PT. BPRS GEBU PRIMA $</$ h2 $><$ address class $=$ "style 1 $<$ p $>$ MEDAN JALAN A.R.HAKIM NO $139<$ p $><$ p $>$ MEDAN - INDONESIA $</$ p $>$ $<$ p $>$ gebu.prima@yahoo.com $</$ p $>\quad</$ address $>$

$<$ span class $=$ "style $1 "><$ br $/></$ span $>$

$<$ h2 class $=$ "style1" $>$ Social $</$ h2 $>$

\section{Kesimpulan}

Kesimpulan yang diperoleh penulis darri hasil penelitian dan rancang bangun dalam pembuatan website pada PT. BPR Syariah Gebu Prima ini, maka berdasarkan hasil penelitian yang telah diuraikan didapat beberapa kesimpulan sebagai berikut :

1. Dengan adanya website ini dapat membantu masyarakat luas untuk mengetahui tentang profil perusahaan PT. BPR Syariah Gebu Prima.

2. Dapat membantu perusahaan dalam memprosikan produk - produk serta mengenal lebih jauh tentang PT. BPR Syariah Gebu Prima. 


\section{REFERENCES}

Agus, S. (2012). Webtips : PHP, HTML Java, dan CSSe. Cirebon: PT. Jasakom.

Batubara, A., \& Hidayat, R. (2016). Pengaruh Penetapan Harga dan Promosi terhadap Tingkat Penjualan Tiket pada PSA Mihin Lanka Airlines. Jurnal Ilman, 4(1), 33-46.

Cece. (2003). Analisis Hubungan Perencanaan Strategi Aliansi PDAM Tirtanadi-PT. Telekominikasi Divre I Terhadap Peningkatan Kualitas Pelayanan Pelanggan PDAM Tirtanadi... Universitas Sumatera Utara.

Dinamika, S. G. (2018). Gemstone Fever Hits Jakarta: A Lexical Meaning Analysis.

Dinamika, S. G., \& Sari, W. V. (2015). Applied Error Analysis of Comparative Degree Sentence Construction of Students in STIM Sukma Medan. Asian EFL Journal, 5, 112-119.

Dinamika, S. G., \& Siregar, E. B. A. (2016). Developing English Syllabus for Tourism Management Students. In Proceedings of the Fourth International Seminar on English Language and Teaching (ISELT-4) (Vol. 13, pp. 16-17).

Dinamika, Soraya Grabiella (2014) THE EFFECT OF USING COLLABORATIVE STRATEGIC READING ON STUDENTS' ACHIEVEMENT IN READING NARRATIVE TEXT. Undergraduate thesis, UNIMED

Fathimah, V. (2017). Pengaruh Perkembangan Jumlah Tabungan, Deposito dan Bagi Hasil terhadap Jumlah Pembiayaan yang Diberikan oleh Perbankan Syariah di Sumatera Utara. Jurnal Ilman, $5(1), 41-52$.

Hernita, P. (2013). Adobe Dreamwaever CS6. Yogyakarta: Andi.

Hikmah, B. A., Supriadi, \& Alawiyah, \&. (2015). Cara cepat membangun website dari nol. Yogyakarta: Andi.

Kendall, K. L. (2012). System Analysis and Desaign (8th ed.). Jakarta: PT. Prenhallindo.

Kurniawan (2013). Perancangan website profil bisnis pada pabrik gula PT.Gondang Baru Klaten. Semarang: Universitas Dipenogoro

Lubis, D. I. D., \& Hidayat, R. (2017). Pengaruh Citra Merek dan Harga terhadap Keputusan Pembelian pada Sekolah Tinggi Ilmu Manajemen Sukma Medan. Jurnal Ilman, 5(1), 15-24.

Nasution, W. A. (2009). Pengaruh kepuasan kerja karyawan terhadap intensi turnover pada call center Telkomsel di Medan. Jurnal Mandiri, 4(1), 1-11.

Nasution, W. A. (2013). Pengaruh kompensasi dan lingkungan kerja terhadap kepuasan kerja karyawan pada PT. Karya Deli Stelindo Medan. Jurnal Manajemen Bisnis STIE IBBI, 20(2), 177.

Nasutiona, L. K., Fahrurb, M., Christine, Imaduddind, \& Wardayani. (2017). The Calculation of Cost of Goods Sold "Gayo Arabica Coffee from Takengon" with Variable Costing Method. Journal Online Jaringan COT POLIPD (JOJAPS), 10, 82-87.

Ningratri, Y. A. (2017). Analisis Pengaruh Strategi Bauran Pemasaran Jasa (3P) terhadap Keputusan Mahasiswa Memilih STIM Sukma Medan. Riset \& Ejurnal Manajemen Informatika, 3(1), 5056.

Nurlinda, \& Wardayani. (2014). Pengaruh Partisipasi Penyusunan Anggaran Dan Penggunaan Instrumen Manajemen Terhadap Kinerja Pengelolaan Dana Bantuan Global Fund Komponen Aids Pada Kementerian Kesehatan Ri. Jurnal Ilman, 1(1), 23-35.

Prana, R. R. (2016). Analisis Faktor-faktor yang Mempengaruhi Pendapatan Asli Daerah (PAD) Kota Tebing Tinggi. Jurnal Ilman, 4(1), 74-86.

Raidani, Pertiwi, L. S., Wulandari, D. Y., \& Zuhri. (2016). Tobit and Interval Censored Regression Model. Global Journal of Pure and Applied Mathematics, 12(1), 981-994. 
Sabdillah, R., Hidayat, R., Lubis, D. S. W., \& Wardayani. (2017). Influence of Celebrity Endorser Raisa Andriana in Advertisement on Magnum Ice Cream Brand Image on the Transmart Costumers. Journal Online Jaringan Pengajian Seni Bina (JOJAPS), 10, 112-115.

Safriandi, F., Pertiwi, L. S., Fitriani, A., \& Zuhri. (2016). Truncated Regression Model and Nonparametric Estimation for Gifted and Talented Education Program. Global Journal of Pure and Applied Mathematics, 12(1), 995-1002.

Setiawan, R. (2012). Pemograman Dasar. Jakarta: Informatika.

Sibero. (2012). Kitab Suci Web Programing. Yogyakarta: Mediakom.

Sidik (2012).Webtips:PHP,HTML,dan CSS3.Cirebon:PT.Jasakom.

Sinaga, S., Pertiwi, L. S., Ardian, T., \& Zuhri. (2016). Inventory Simulation Optimization Under Non

Stationary Demand. International Journal of Applied Engineering Research, 11(1), 524-529

Sinuhaji, E. (2010). PENERAPAN LAYANAN UNGGUL DALAM PEMASARAN PRODUK BANK. Jurnal Mediasi, 2(1).

Sinuhaji, E. (2013). PENGARUH BUDAYA ORGANISASI TERHADAP KEPUASAN KERJA KARYAWAN PADA JASA PERHOTELAN (Studi Kasus di Garuda Plaza Hotel Medan). Bisnis Administrasi, 2(1), 2537.

Sinuhaji, E. (2014). Pengaruh Kepribadian, Kemampuan Kerja dan Motivasi Kerja terhadap Kinerja SDM Outsourcing pada PT. Catur Karya Sentosa Medan. Jurnal Ilman, 1(1), 11-22.

Subhan, M. (2012). Analisa Perancangan Sistem. Yogyakarta: Andi.

Sudarsono(2012).Analisis Komparatif kinerja Bank Syariah. Jakarta: Universitas Yarsi

Sukendro, H. A. (2012). Pengaruh Citra Merek dan Kualitas Pelayanan terhadap Kepuasan Jama'ah pada Kelompok Bimbingan Ibadah Haji (KBIH) Indosat Medan. Universitas Terbuka.

Sunyoto, D. (2014). Sistem Informasi Manajemen. Yogyakarta: Center Of Academic Publishing Service.

Sutabri, T. (2012). Analisis Sistem Informasi. Yogyakarta: CV Andi Offset.

Sutarman (2012).Analisis dan PerancanganSistem Informasi. Palembang: Politeknik Negeri Sriwijaya.

Wahyuni, D. S., \& Wardayani. (2016). Analisis Return on Asset, Current Ratio dan Debt Ratio dalam Menilai Kinerja Keuangan pada PT . Pelabuhan Indonesia I (Persero) cabang Belawan. Jurnal Ilman, 4(1), 59-73.

Widjanarko, B. (2015). PENGARUH PEMERIAN KOMPENSASI DAN KOMUNIKASI TERHADAP SEMANGAT KERJA KARYAWAN PADA BUMI KARYA TAMA INSURANCE CABANG MEDAN. Jurnal Research Sains, 1(2), 130-152.

Winata, E. (2016). Pengaruh Kepuasan Kerja dan Kompensasi terhadap Kinerja Karyawan pada Hotel Inna Dharma Deli Medan. Jurnal Ilman, 4(1), 1-17.

Winata, E. (2016). PENGARUH KOMPENSASI DAN KOMUNIKASI TERHADAP SEMANGAT KERJA KARYAWAN PADA PT. FIF CABANG MEDAN. Jurnal Dunia Ilmu, 2(1), 17-31.

Winata, E. (2017). PENGARUH BAURAN PEMASARAN JASA TERHADAP LOYALITAS KONSUMEN PADA GRAND SERELA HOTEL \& CONVENTION MEDAN. Jurnal Mutiara Manajemen, 1(1), 109-121. 